\title{
Swedish healthcare management practices and quality improvement work - development trends
}

Mattias Elg, Jesper Stenberg, Peter Kammerlind, Sofia Tullberg and Jesper Olsson

\section{Linköping University Post Print}

N.B.: When citing this work, cite the original article.

Original Publication:

Mattias Elg, Jesper Stenberg, Peter Kammerlind, Sofia Tullberg and Jesper Olsson, Swedish healthcare management practices and quality improvement work - development trends, 2011, International journal of health care quality assurance/MCB University Press, (24), 2, 101-123. http://dx.doi.org/10.1108/09526861111105077

Copyright: Emerald http://www.emeraldinsight.com/

Postprint available at: Linköping University Electronic Press

http://urn.kb.se/resolve?urn=urn:nbn:se:liu:diva-77456 


\title{
Developmental Trends in Management Practices and Quality Improvement Work in Swedish Healthcare
}

\author{
Mattias Elg \\ Division of Quality Management and Technology, HELIX Research Centre, Linköping \\ university, Sweden
}

Jesper Stenberg

Medical Management Centre, Karolinska Institute, Stockholm, Sweden

Peter Kammerlind,

Qulturum, County Council of Jönköping, Sweden

Sofia Tullberg

Swedish Association of Local Authorities and Regions, Stockholm, Sweden

Jesper Olsson

Swedish Association of Local Authorities and Regions, Stockholm, Sweden

Corresponding author: mattias.elg@liu.se

\section{Abstract}

Purpose - This study aims at empirically examining developmental trends in management practices and improvement work in healthcare organizations.

Design/methodology/approach - We surveyed the managers of all primary healthcare centers $(n=1031)$ and clinical hospital departments $(n=1542)$ nationwide in the spring of 2007 . The response rate was $46 \%$. This article compares results from this survey with a study that was made in 2003. A theoretical framework based on organizational inner context, organizational outer context, external environment and outcomes form the base for the analysis. Comparisons were made using an independent two-sample t-test.

Findings - A general aspect, identified empirically, is the tendency toward increased external pressure on the leaders in their improvement work. Higher management decisions, patient pressure and decisions made by policymakers have increasingly influenced and shaped the choices made by health care managers about where to focus efforts of improvement. Three different trends are empirically identified and elaborated upon in the article: Take-control logics; practice-based improvement and patient-centeredness.

Practical implications - Health care leaders should carefully design new management control systems so that they support healthcare micro systems in their improvement 
work. The findings support the general assumption that organizations increasingly tend to focus organizational changes on management control.

Originality/value - This study provides the scholarly field of management research with a unique survey. Through two measurements made 2003 and 2007 we identify several trends of importance for how healthcare organizations are managed and developed.

Keywords - Management practice, improvement, quality, healthcare

Paper type - Research paper

\section{Introduction}

The Swedish healthcare system produces high quality healthcare for a reasonable cost (Nolte and McKee, 2003). Like other western industrialized countries, the Swedish healthcare system has at least three oncoming challenges to manage: demographic changes (Nolte and McKee, 2003), medical and technological advances (Swedish Code of Statutes, 1976; Bourgeois et al, 1978; Borgert, 1992; Banta et al, 1993; Cutler et al 2001; Anell, 2005; Quality and Efficiency in Swedish Health Care - Regional Comparisons 2007) and citizen's expectations from being a demanding and well-informed healthcare co-actor (Anell, 2005). At the same time the financial resources allocated to healthcare are not expected to increase. A general opinion is that strategies other than financial increases have to be considered.

Even though the Swedish healthcare system is indeed a national one, it is quite decentralized (Borgert, 1992). The 21 county councils have far-reaching responsibilities for financing and providing healthcare for their citizens (Swedish Code of Statutes, 1976). The decentralized system enables difference in organizational structures as well as in the character of local healthcare reforms (Anell, 2005). Variation also includes medical and financial results (Quality and Efficiency in Swedish Health Care - Regional Comparisons 2007).

Management and leadership skills and systems play a fundamental part when coping with these somewhat conflicting challenges. It is generally claimed that increased effectiveness is about continually transforming and changing the operation in order to meet changing conditions. It is also about making flexible, successive adaptations to changing needs for treatment and new technology and knowledge, as well as changing values and lifestyles.

Enhancing the understanding of how healthcare organizations deal with these pressures is of central importance. What are the developmental trends in management practices and improvement work in healthcare organizations? What kind of work is done in order 
to deal with the changing demands for care? These are central questions that we aim to answer in this article.

There appears to be a gap in research that explicitly studies developmental trends in management practices in healthcare. We have identified examples of empirical research that provide evidence of management practices as part of case studies over short-term periods (see e.g. Thompson, Gail and Steven, 2003). Further, textbooks on organization theory and management practices often describe the development of management practices theoretically over long time spans, ranging from scientific management traditions to postmodernism and neo-institutionalism (Scott and Gerald, 2006). These kinds of overviews give important contributions about general, theoretical development. However, we have not identified any empirical studies comparing and analysing the quality improvement trends over time in health care organizations.

In 2003 we studied how Swedish healthcare organizations work with improvement activities. We developed the concept of an internal collaborative strategy (ICS) as a way to represent the general view of improvement work. The internal aspect of the ICS referred to our finding that most activities were both derived and performed from within the studied healthcare organization. The drivers for improvement were mainly good ideas from members within the organization, their perceptions of dysfunctional daily work, and problems regarding staff/work environment. The collaborative aspects of the IC strategy revealed that many members of the organization, with different organizational roles, participated in the improvement work - both in planning and execution.

In this article, we present results from studying developmental trends between 2003 and 2007. Our study compares results from the questionnaire which was sent out to Swedish Health Care Leaders 2003 and a subsequent measurement in 2007. The research questions we aim to answer are:

- What are the significant differences in general opinions about improvement work?

- What are the significant differences in drivers for change?

- What are the results of change initiatives?

The basis for our work is a questionnaire which was developed in 2003 (see Olsson et al., 2003).

\section{Study design and data}

\section{Questionnaire design}

The questionnaire for 2007 used the survey from 2003 as its base. This previous survey was developed, at the request of the Swedish Federation of County Councils, by quality 
improvement practitioners and researchers through a four-step process. First, a draft questionnaire was formed based on experts' ideas and on change management literature. Second, the draft questionnaire was discussed with clinical facilitators from Skellefteå Medical Services and tested with a small group of healthcare managers there. Third, after improving the questionnaire according to comments and experiences from that test, the modified questionnaire was tested by a small group of managers. Fourth, based on the experiences from these tests, we constructed the final questionnaire. The model, which is the base for our study. is related to the internal structure and processes of the organization. Van de Ven et al. (2000) as well as Porras and Robertson (1992) suggest several aspects that should be taken into account when studying this internal dimension. Based on these ideas, the following has been considered:

1. Organizational conditions - define the structure of the organization in terms of location, size, type, and people engaged in improvements.

2. Barriers to change-cover various organizational barriers that may cause difficulties in conducting change initiatives.

3. Problem areas - define a range of various organizational problems as perceived by members of the organizations.

4. Method-the means by which organizations undertake efforts to solve their problems. This includes concepts, ideas, and methods ranging from education and problem analysis to introduction of new medical technologies.

5. Outcomes-describes various results of the interventions.

The second survey, developed in 2007, had the following additional features:

- Comprehensive measurements of the results dimension

- A set of measurements related to process management

- A set of measurements related to patient safety

- Refined methods section with addition of quality improvement tools

\section{Data Collection and analysis}

We surveyed the managers of all primary healthcare centers $(n=1031)$ and clinical hospital departments $(n=1542)$ nationwide in the spring of 2007. The survey was carried out by the Linfab Company (company Web site [in Swedish]: www.linfab.se). They identified respondents through an address database of healthcare providers. Participation in the survey was based on informed consent and respondents were granted total confidentiality. The sole criterion for inclusion was that the primary care center/department provides direct services to patients (so, for example, labs with no patient contact were excluded).

The questionnaire, along with an instructional cover letter from the Swedish Association of Local Authorities and Regions, was mailed to managers at primary healthcare centers and hospital departments during February/March . After this date, reminders were mailed to non-responders. Later on, reminders were also given by telephone and fax. 
After three unsuccessful attempts at telephone contact, non-responding managers received a new copy of the questionnaire in the mail as a final reminder.

About one third of respondents replied without any reminders, before the deadline. According to the study project plan, data collection was closed on May 8, 2007, even though responses were still arriving. By this date responses had arrived from $454(44 \%)$ primary healthcare centers and $725(47 \%)$ hospital departments, a total response rate of $46 \%$.

Data analysis was carried out using the following software: SPSS version 15, MS Excel for Windows 2000.

\section{Analysis of non-responders}

A qualitative non-respondent analysis was chosen. We identified that the address registry used to identify the population was inadequate. Consequently, organizational changes that had been made and staff turnovers were not fully reflected in the address list. This added up to 150 non-responders that we defined as a natural reduction of possible responders, which were reduced from the total sample.

Major reasons for non-responders were that they did not answer because of a lack of time, the extent of the survey, and the degree of difficulty of the questions, while some of the non-responders felt that the subject of the survey did not concern them and that they should not have been included in the sample. Some of the non-responders stated that they were simply not interested.

\section{Results}

The overall picture in the comparison of material from 2007 and 2003 is that there are several developmental trends of importance. We see a widening scope for improvement work in healthcare systems. There is for example more external influence on the leaders in their improvement work. In particular we see that higher management decisions, the voice of the patient and decisions made by policymakers increasingly influence and shape the quality improvement efforts of healthcare managers. These trends are further presented in subsequent sections.

\section{Characteristics of responders and their units}

The characteristics of the respondents and their organizational units are similar to the study from 2003. In $84 \%$ of the cases, the head of the organization answered the survey compared to $88 \%$ in 2003 , whereas in $5 \%$ the assistant head responded compared to $7 \%$. Of all respondents, 55\% were female (compared to 51\% in 2003). The size distribution of the respondents' organizational units are shown in Figure 1. The distributions are almost 
identical and it is worth noting that half of the organizational units have between 21-100 employees.

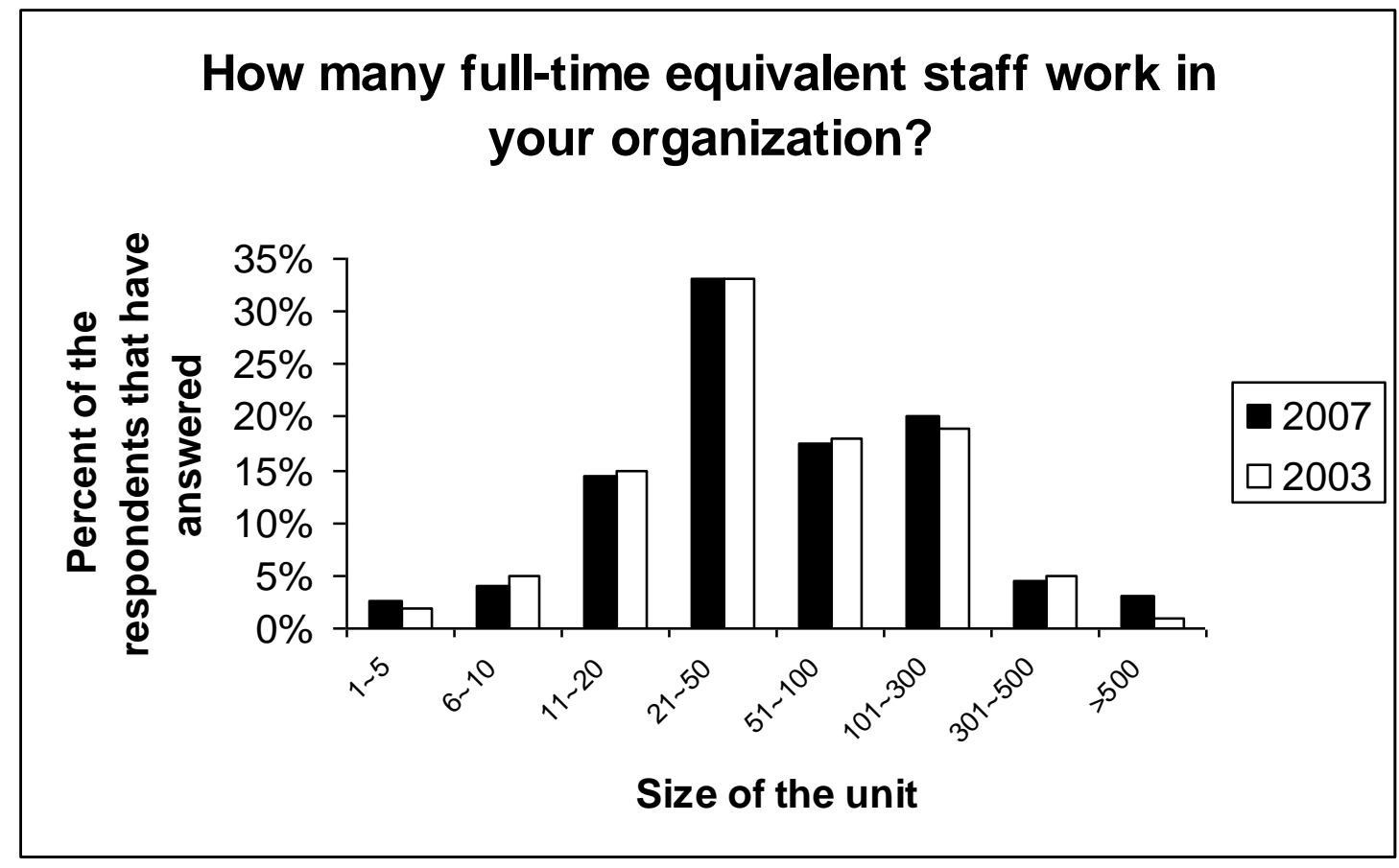

Figure 1. The size distribution of the respondents' organizational units On the question "What share of the physicians in your setting have been actively involved in your improvement work over the past 12 months?" and the question "What share of your employees have been involved in your improvement work over the past 12 months?", about $34 \%$ of respondents indicated that $81 \%-100 \%$ of staff or physicians were involved in the improvement work, compared to 35\% in 2003.

\section{General ideas about improvement work}

The general opinion of improvement work in 2007 in Swedish healthcare is similar to 2003. Table 1 shows the number of respondents, means, and standard deviations for all the statements that were posted under the theme "To what extent do you think that the following statements agree with general opinion regarding improvement work in your organizational unit?". The results from analyzing this data are that only one of the questions differs $(\mathrm{p}<0.05)$ : The guidance available for improvement work is insufficient. Thus, the practitioners experience a slight improvement for how to organize and structure improvement work.

As in the 2003 survey, improvement work is considered to be something positive, it meets current needs in the daily operations, and it is considered to yield distinctive results. All these variables have a relatively high rating in the two measurements from 2003 and 2007. 
- Working paper, do not distribute - 
Table 1. General ideas about improvement work, "To what extent do you think that the following statements agree with general opinion regarding improvement work in your organizational unit?" 1 do not agree -5 strongly agree

\begin{tabular}{|c|c|c|c|c|c|}
\hline & År & $\mathrm{N}$ & Mean & $\begin{array}{c}\text { Std. } \\
\text { Deviation }\end{array}$ & Significance \\
\hline \multirow[t]{2}{*}{ Improvement work is something positive here } & 2003 & 900 & 4,42 & 0,671 & \multirow{2}{*}{ Not sign. } \\
\hline & 2007 & 1162 & 4,41 & 0,658 & \\
\hline \multirow{2}{*}{$\begin{array}{l}\text { Improvement work meets current needs in } \\
\text { our operations }\end{array}$} & 2003 & 899 & 3,87 & 0,748 & \multirow{2}{*}{ Not sign. } \\
\hline & 2007 & 1168 & 3,85 & 0,740 & \\
\hline \multirow{2}{*}{$\begin{array}{l}\text { Improvement work is consistent with our } \\
\text { norms and values }\end{array}$} & 2003 & 891 & 3,98 & 0,730 & \multirow{2}{*}{ Not sign. } \\
\hline & 2007 & 1033 & 4,01 & 0,711 & \\
\hline \multirow{2}{*}{ Improvement work yields distinctive results } & 2003 & 894 & 3,95 & 0,737 & \multirow{2}{*}{ Not sign. } \\
\hline & 2007 & 1163 & 3,97 & 0,722 & \\
\hline \multirow{2}{*}{$\begin{array}{l}\text { The guidance available for improvement is } \\
\text { insufficient }\end{array}$} & 2003 & 897 & 2,35 & 1,087 & \multirow{2}{*}{ Not sign. } \\
\hline & 2007 & 1159 & 2,42 & 1,062 & \\
\hline \multirow{2}{*}{$\begin{array}{l}\text { Improvement work conflicts with our daily } \\
\text { work tasks }\end{array}$} & 2003 & 898 & 2,77 & 1,120 & \multirow{2}{*}{ Not sign. } \\
\hline & 2007 & 1168 & 2,77 & 1,059 & \\
\hline \multirow{2}{*}{$\begin{array}{l}\text { Improvement initiatives are difficult to test on } \\
\text { a limited scale }\end{array}$} & 2003 & 884 & 2,60 & 0,920 & \multirow{2}{*}{ Not sign. } \\
\hline & 2007 & 1072 & 2,57 & 0,896 & \\
\hline \multirow{2}{*}{$\begin{array}{l}\text { Approaches to, and methods for, } \\
\text { improvement are difficult to use }\end{array}$} & 2003 & 889 & 2,80 & 0,972 & \multirow{2}{*}{$p<0.05$} \\
\hline & 2007 & 1155 & 2,70 & 0,969 & \\
\hline \multirow{2}{*}{$\begin{array}{l}\text { Improvement work is in conflict with the } \\
\text { roles and positions of different professional }\end{array}$} & 2003 & 890 & 2,63 & 1,102 & \multirow{2}{*}{ Not sign. } \\
\hline & 2007 & 1136 & 2,60 & 1,079 & \\
\hline
\end{tabular}




\section{Drivers for change}

The "drivers for change" theme in the questionnaire is based on aspects that influence change initiatives. In order to characterize the changes between 2003 and 2007 we have distinguished between forces that come from within the organization and those that come from outside. This categorization is based on the findings from the 2003 study, in which we identified several internal drivers for change (Olsson, Kammerlind, Thor and Elg, 2003).

The framework of the present study is based on three different types of drivers for change. First, the organizational inner context consists of the structure, activities, problem areas, applications and usage of methods of improvement within the organization. Second, the organizational outer context is related to the immediate environmental aspects of the organizations such as patients, higher management and other healthcare providers. Third, the external environment, which, through policy makers and various professional organizations, influences improvement activities within the studied organizations.

Answers to the question "To what extent have the following items been driving forces for your improvement work?" are shown in Figure 2. This comparison between 2003 and 2007 is based on 11 variables. In the table, variables are ranked in order by the differences in their means. The table shows the variable, its categorization, number of respondents $(\mathrm{N})$, means, standard deviation and significance.

The most important trends in drivers for change are derived from patient needs/complaints, decisions from higher-level managers and directives from official authorities. Also, problems regarding the quality of healthcare and the fact that daily work does not function optimally show significance change. In addition to these factors, problems regarding access to health care have slightly increased as a driver.

Drivers that show no significant difference are financial problems, that is, financial issues have not changed in any direction. This driver is also low ranked (number ten of the eleven drivers for change) with a mean of 2.85 on a scale from 1 to 5 . No significant change is identified for the driver Medical innovations. The two drivers, Desire to increase market share and Problems regarding staff/the work environment have not changed during 2003 and 2007.

Good ideas from employees is the only driver that shows a significant decrease since 2003. 
Table 2 Drivers for change: ranking according to the difference in means from 2003-2007. Significant variables are highlighted.

\begin{tabular}{|c|c|c|c|c|c|c|c|}
\hline $\begin{array}{c}\text { Rank order } \\
\text { (difference in means 2003- } \\
\text { 2007) } \\
\end{array}$ & Measurement & Source & Year & $N$ & Mean & $\begin{array}{l}\text { Standard } \\
\text { deviation }\end{array}$ & Significance \\
\hline \multirow[b]{2}{*}{1} & \multirow[b]{2}{*}{ Patient needs/complaints } & \multirow{2}{*}{$\begin{array}{l}\text { Organizational outer- } \\
\text { context }\end{array}$} & 2003 & 891 & 2,81 & \begin{tabular}{|r|}
1,073 \\
\end{tabular} & \multirow{2}{*}{$\mathrm{p}<0.01$} \\
\hline & & & 2007 & 1155 & 3,17 & 1,110 & \\
\hline \multirow[b]{2}{*}{2} & \multirow[b]{2}{*}{ Decisions from higher level managers } & \multirow{2}{*}{$\begin{array}{l}\text { Organizational outer- } \\
\text { context }\end{array}$} & 2003 & 892 & 2,69 & 1,045 & \multirow{2}{*}{$p<0.01$} \\
\hline & & & 2007 & 1139 & 3,04 & 1,095 & \\
\hline \multirow[b]{2}{*}{3} & \multirow{2}{*}{$\begin{array}{l}\text { Directives from official } \\
\text { authorities; laws and regulations }\end{array}$} & \multirow[b]{2}{*}{ External environment } & 2003 & 890 & 2,87 & 0,997 & \multirow{2}{*}{$\mathrm{p}<0.01$} \\
\hline & & & 2007 & 1157 & 3,16 & 1,047 & \\
\hline \multirow[b]{2}{*}{4} & \multirow{2}{*}{$\begin{array}{l}\text { Problems regarding the } \\
\text { quality of health care }\end{array}$} & \multirow{2}{*}{$\begin{array}{l}\text { Organizational inner- } \\
\text { context }\end{array}$} & 2003 & 887 & 2,96 & 0,993 & \multirow{2}{*}{$p<0.01$} \\
\hline & & & 2007 & 1158 & 3,12 & 1,078 & \\
\hline \multirow[b]{2}{*}{5} & \multirow{2}{*}{$\begin{array}{l}\text { Daily work does } \\
\text { not function optimally }\end{array}$} & \multirow{2}{*}{$\begin{array}{l}\text { Organizational inner- } \\
\text { context }\end{array}$} & 2003 & 893 & 3,67 & 1,005 & \multirow{2}{*}{$p<0.01$} \\
\hline & & & 2007 & 1152 & 3,83 & 0,992 & \\
\hline \multirow[b]{2}{*}{6} & \multirow{2}{*}{$\begin{array}{l}\text { Problems regarding } \\
\text { access to health care }\end{array}$} & \multirow{2}{*}{$\begin{array}{l}\text { Organizational outer- } \\
\text { context }\end{array}$} & 2003 & 892 & 3,36 & 1,157 & \multirow{2}{*}{$\mathrm{p}<0.01$} \\
\hline & & & 2007 & 1141 & 3,51 & 1,178 & \\
\hline \multirow[b]{2}{*}{7} & \multirow[b]{2}{*}{ Financial problems } & \multirow{2}{*}{$\begin{array}{l}\text { Organizational outer- } \\
\text { context }\end{array}$} & 2003 & 894 & 2,76 & 1,103 & \multirow{2}{*}{ not sign. } \\
\hline & & & 2007 & 1158 & 2,84 & 1,136 & \\
\hline \multirow[b]{2}{*}{8} & \multirow[b]{2}{*}{ Medical innovations } & \multirow[b]{2}{*}{ External environment } & 2003 & 888 & 3,32 & 0,909 & \multirow{2}{*}{ not sign. } \\
\hline & & & 2007 & 1104 & 3,32 & 0,978 & \\
\hline \multirow[b]{2}{*}{9} & \multirow{2}{*}{$\begin{array}{l}\text { The desire to increase } \\
\text { our market share }\end{array}$} & & 2003 & 883 & 2,10 & 1,175 & not sign \\
\hline & & External environment & 2007 & 1119 & 2,04 & 1,188 & \\
\hline & Problems regarding & Organizational inner- & 2003 & 892 & 3,52 & 0,972 & not sign. \\
\hline 10 & staff/the work enironment & context & 2007 & 1141 & 3,36 & 1,038 & \\
\hline & Good ideas & Organizational inner- & 2003 & 898 & 4,00 & 0,761 & $\mathrm{p}<0.01$ \\
\hline 11 & from employees & context & 2007 & 1161 & 3,86 & 0,795 & \\
\hline
\end{tabular}




\section{Methods/concepts for improvement in change initiatives}

One set of questions concerns to what extent respondents assess that their organizational unit has been using a number of different methods/concepts. In total, this theme includes 34 variables. In this study, we have classified these methods/concepts into seven categories. See Table 3 below.

Table 3. Classifications of difference methods/concepts under study

\begin{tabular}{|c|c|c|c|}
\hline $\begin{array}{l}\text { Classification } \\
\text { categories based on } \\
\text { method/concept } \\
\text { used in the } \\
\text { questionnaires }\end{array}$ & Definition & $\begin{array}{l}\text { Examples from the } \\
\text { questionnaire }\end{array}$ & $\begin{array}{l}\text { References } \\
\text { where type of } \\
\text { method/con- } \\
\text { cept is } \\
\text { presented }\end{array}$ \\
\hline Problem analysis & $\begin{array}{l}\text { Formal activities for } \\
\text { collecting, structuring, } \\
\text { rearranging, analyzing } \\
\text { and interpreting practice } \\
\text { based data }\end{array}$ & $\begin{array}{l}\text { Risk analysis, } \\
\text { Analyses of } \\
\text { incidents, Process } \\
\text { mapping }\end{array}$ & $\begin{array}{l}\text { Bergman and } \\
\text { Klefsjö (2003); } \\
\text { Ellström (2006) }\end{array}$ \\
\hline $\begin{array}{l}\text { Organizational } \\
\text { behavior change }\end{array}$ & $\begin{array}{l}\text { Rearrangements of } \\
\text { organizational members' } \\
\text { patterns of behavior so } \\
\text { that work flows and other } \\
\text { activities are improved }\end{array}$ & $\begin{array}{l}\text { Breakthrough type } \\
\text { efforts, changing } \\
\text { care pathways, } \\
\text { treatment methods, } \\
\text { change division of } \\
\text { tasks } \\
\end{array}$ & $\begin{array}{l}\text { Beer et al. } \\
\text { (2000); Olsson } \\
\text { (2003); King et } \\
\text { al (2006) }\end{array}$ \\
\hline $\begin{array}{l}\text { Medical/manage- } \\
\text { ment control } \\
\text { systems }\end{array}$ & $\begin{array}{l}\text { The formal, information- } \\
\text { based routines and } \\
\text { procedures managers, } \\
\text { clinicians and policy } \\
\text { makers use to maintain or } \\
\text { alter patterns in } \\
\text { organizational activities }\end{array}$ & $\begin{array}{l}\text { Electronic medical } \\
\text { records, Balanced } \\
\text { Scorecards, Quality } \\
\text { registers, } \\
\text { Administrative } \\
\text { information systems }\end{array}$ & $\begin{array}{l}\text { Simons (1995); } \\
\text { Neely et al. } \\
(2002) ; \text { Elg } \\
(2001)\end{array}$ \\
\hline Patient orientation & $\begin{array}{l}\text { Activities made by } \\
\text { members of the } \\
\text { organization aiming at } \\
\text { increasing the patient's } \\
\text { role within the healthcare } \\
\text { system }\end{array}$ & $\begin{array}{l}\text { Quality } \\
\text { Improvement based } \\
\text { on patient } \\
\text { satisfaction }\end{array}$ & $\begin{array}{l}\text { Bergman and } \\
\text { Klefsjö (2003); } \\
\text { Thompson et } \\
\text { al (2003) }\end{array}$ \\
\hline $\begin{array}{l}\text { Information/comm } \\
\text { unication /training }\end{array}$ & $\begin{array}{l}\text { Types of activities } \\
\text { focusing on changing } \\
\text { attitudes and knowledge }\end{array}$ & $\begin{array}{l}\text { Developing method } \\
\text { descriptions and } \\
\text { guidelines, }\end{array}$ & $\begin{array}{l}\text { Kazandijan } \\
\text { and Lied } \\
(1999) ;\end{array}$ \\
\hline
\end{tabular}




\begin{tabular}{|l|l|l|l|}
\hline & $\begin{array}{l}\text { among members of the } \\
\text { organization }\end{array}$ & $\begin{array}{l}\text { Information to } \\
\text { patients and staff, } \\
\text { support from } \\
\text { consultants, } \\
\text { educational } \\
\text { initiatives }\end{array}$ & $\begin{array}{l}\text { Davenport and } \\
\text { Prusak (1999) }\end{array}$ \\
\hline Financial control & $\begin{array}{l}\text { Activities directed } \\
\text { towards the financial } \\
\text { aspects of the } \\
\text { organization }\end{array}$ & $\begin{array}{l}\text { Acquisition of } \\
\text { additional financial } \\
\text { resources, Reward } \\
\text { systems }\end{array}$ & Simons (1995) \\
\hline $\begin{array}{l}\text { Organization } \\
\text { structure change }\end{array}$ & $\begin{array}{l}\text { Initiatives aimed at } \\
\text { merging, splitting or } \\
\text { rearranging the relations } \\
\text { between organizational } \\
\text { units }\end{array}$ & $\begin{array}{l}\text { Physical work } \\
\text { environment, } \\
\text { Administrative } \\
\text { organizational } \\
\text { structure change }\end{array}$ & $\begin{array}{l}\text { Pugh et al. } \\
(1968), \\
\text { Pettigrew et al. } \\
(1992) ; \\
\text { Olsen (1998); } \\
\text { Mintzberg } \\
(1979)\end{array}$ \\
\hline
\end{tabular}

The results are shown in Table 4 (Methods/concepts that have increased in use between 2003 and 2007), Table 5 (Methods/concepts that have not changed in use 2003-2007), and Table 6 (Methods/concepts that have decreased in use between 2003-2007).

Each table presents the method/concept, category, number of respondents $(\mathrm{N})$, mean, standard deviation and significance. The order of presentation is based on the rank (i.e. differences in means 2007 and 2003).

Significant positive trend

The greatest difference between 2003 and 2007 is found in the use of Other systematic development methods which are used systematically. Breakthrough-type efforts show a big difference and is the single method/concept that shows greatest difference from 2003 to 2007. Methods/concepts - which we have classified as medical/management control systems - such as the electronic medical record, national quality registers, administrative information systems, balanced scorecard and management review systems also show significant greater use.

Patient orientation is another important aspect that is of increased importance within the studied organizations. A third emerging trend is the increased focus on problem analysis, i.e. Formal activities for collecting, structuring, rearranging, analyzing and interpreting practice-based data.

Status quo factors 
The methods/concepts found in the status quo group are diverse and range from behavior change aspects to information/communication/training. We note that Evidence Based Medicine is among the concepts that have not changed in use from 2003 to 2007. Also, there is no difference regarding the division of work assignment, staff scheduling system and improving the physical work environment. Systematic improvements of care pathways that cross organizational boundaries, an area which has been under scrutiny in recent years, shows no significant difference. Methods of education such as training in quality improvement as well as leadership development have not changed during the years of this study, but are still on a high level and ranked in the top ten methods/concepts.

Negative trends

Finally, the study shows trends of decreased $(p<0.01)$ use in three different areas: National/international/regional quality awards; Acquisition of additional financial resources (compare with the not significant financial problems from drivers of change); and reward systems. 
- Working paper, do not distribute -

Table 4. Methods/concepts that have increased in use between 2003 and 2007

\begin{tabular}{|c|c|c|c|c|c|c|c|}
\hline $\begin{array}{c}\text { Rank order } \\
\text { (difference in means 2007- } \\
\text { 2003) }\end{array}$ & Measurement & Category & Year & $N$ & Mean & $\begin{array}{l}\text { Standard } \\
\text { deviation }\end{array}$ & Significance \\
\hline \multirow[t]{2}{*}{1} & \multirow{2}{*}{$\begin{array}{l}\text { Other specific development methods which are used } \\
\text { systematically }\end{array}$} & \multirow[t]{2}{*}{ Other } & 2003 & 477 & 1,22 & 0,415 & \multirow{2}{*}{$\mathrm{p}<0.01$} \\
\hline & & & 2007 & 900 & 2,11 & 1,297 & \\
\hline \multirow[t]{2}{*}{2} & \multirow{2}{*}{ Risk analysis } & \multirow[t]{2}{*}{ Problem analysis } & 2003 & 835 & 2,00 & 1,229 & \multirow{2}{*}{$p<0.01$} \\
\hline & & & 2007 & 1128 & 2,88 & 1,261 & \\
\hline \multirow[t]{2}{*}{3} & \multirow{2}{*}{$\begin{array}{l}\text { Breakthrough-type efforts, i.e. "Improved flow in } \\
\text { healthcare", "Idealized Design of the Clinical Office }\end{array}$} & \multirow[t]{2}{*}{ Organizational behavior change } & 2003 & 848 & 2,15 & 1,502 & \multirow{2}{*}{$p<0.01$} \\
\hline & & & 2007 & 1129 & 2,80 & 1,565 & \\
\hline \multirow[t]{2}{*}{4} & \multirow[t]{2}{*}{ To implement or develop an electronic medical record } & \multirow[t]{2}{*}{ medical/management control } & 2003 & 838 & 2,60 & 1,580 & \multirow{2}{*}{$\mathrm{p}<0.01$} \\
\hline & & & 2007 & 1105 & 3,17 & 1,660 & \\
\hline \multirow[t]{2}{*}{5} & \multirow[t]{2}{*}{ Balanced Scorecard } & \multirow[t]{2}{*}{ medical/management control } & 2003 & 829 & 2,29 & 1,515 & \multirow{2}{*}{$\mathrm{p}<0.01$} \\
\hline & & & 2007 & 1111 & 2,81 & 1,596 & \\
\hline \multirow[t]{2}{*}{6} & \multirow[t]{2}{*}{ Quality improvement based on patient satisfaction } & \multirow[t]{2}{*}{ Patient orientation } & 2003 & 842 & 2,52 & 1,223 & \multirow{2}{*}{$p<0.01$} \\
\hline & & & 2007 & 1105 & 2,96 & 1,242 & \\
\hline \multirow[t]{2}{*}{7} & \multirow[t]{2}{*}{ The national quality registries } & \multirow[t]{2}{*}{ medical/management control } & 2003 & 841 & 2,63 & 1,426 & $p<0.01$ \\
\hline & & & 2007 & 1128 & 3,07 & 1,357 & \\
\hline 8 & Incremental changes through small scale testing & Organizational behavior change & 2003 & 818 & 2,56 & 1,361 & $2 \leq 001$ \\
\hline & & & 2007 & 1079 & 2,97 & 1,317 & $p<0.01$ \\
\hline 9 & Implementation of Information Systems to support our & medical/management control & 2003 & 847 & 2,77 & 1,474 & \\
\hline & operations (staff administration, telemedicine, digital & & 2007 & 1098 & 3,06 & 1,510 & $p<0.01$ \\
\hline 10 & Changes to the organizational structure & Organizational structure & 2003 & 853 & 2,80 & 1,444 & $n \leq 001$ \\
\hline & & & 2007 & 1129 & 3,00 & 1,387 & $p^{p<0.01}$ \\
\hline 11 & To develop management review systems & medical/management control & 2003 & 846 & 2,53 & 1,245 & \\
\hline & & & 2007 & 1102 & 2,72 & 1,259 & $p<0.01$ \\
\hline 12 & To develop methods descriptions, practice guidelines and & Information/communication/training & 2003 & 872 & 3,18 & 1,222 & $\ln <00$ \\
\hline & instructions etc. & & 2007 & 1139 & 3,37 & 1,196 & $\mathrm{p}<0$ \\
\hline 13 & Increased information through printed materials, overhead & Information/communication/training & 2003 & 857 & 2,32 & 1,178 & $p<0.01$ \\
\hline & visual materials, lectures, etc. & & 2007 & 1130 & 2,51 & 1,187 & \\
\hline 14 & Analysis of incidents where patients have been harmed & Problem analysis & 2003 & 847 & 3,28 & 1,270 & $p<0.01$ \\
\hline & & & 2007 & 1124 & 3,46 & 1,251 & \\
\hline 15 & Process mapping/process description & Problem analysis & 2003 & 839 & 2,60 & 1,313 & $2 \leq 001$ \\
\hline & & & 2007 & 1107 & 2,77 & 1,324 & $p<0.01$ \\
\hline 16 & Systematic improvement of internal care pathways & Organizational behavior change & 2003 & 861 & 3,01 & 1,209 & $n \leq 001$ \\
\hline & & & 2007 & 1118 & 3,18 & 1,188 & $p<0.01$ \\
\hline 17 & To implement new treatment methods & Organizational behavior change & 2003 & 841 & 2,81 & 1,200 & $2 \leq 001$ \\
\hline & & & 2007 & 1095 & 2,97 & 1,184 & $\mathrm{p}<0.01$ \\
\hline 18 & Certification efforts, accreditation efforts, for instance & medical/management control & 2003 & 852 & 1,65 & 1,213 & \\
\hline & through ISO & & 2007 & 1105 & 1,80 & 1,313 & \\
\hline
\end{tabular}


- Working paper, do not distribute -

Table 5 Methods/concepts that have not been changed in use 2003-2007

\begin{tabular}{|c|c|c|c|c|c|c|c|}
\hline $\begin{array}{c}\text { Rank order } \\
\text { (difference in means 2007- } \\
\text { 2003) } \\
\end{array}$ & Measurement & Category & Year & $\mathrm{N}$ & Mean & \begin{tabular}{|l|}
$\begin{array}{l}\text { Standard } \\
\text { deviation }\end{array}$ \\
\end{tabular} & Significance \\
\hline \multirow[t]{2}{*}{1} & \multirow{2}{*}{$\begin{array}{l}\text { Other specific development methods which are used } \\
\text { systematically }\end{array}$} & \multirow[t]{2}{*}{ Other } & 2003 & 477 & 1,22 & \begin{tabular}{r|}
0,415 \\
\end{tabular} & \multirow{2}{*}{$\mathrm{p}<0.01$} \\
\hline & & & 2007 & 900 & 2,11 & 1,297 & \\
\hline \multirow[t]{2}{*}{2} & \multirow[t]{2}{*}{ Risk analysis } & \multirow[t]{2}{*}{ Problem analysis } & 2003 & 835 & 2,00 & 1,229 & \multirow{2}{*}{$\mathrm{p}<0.01$} \\
\hline & & & 2007 & 1128 & 2,88 & 1,261 & \\
\hline \multirow[t]{2}{*}{3} & \multirow{2}{*}{\begin{tabular}{|l} 
Breakthrough-type efforts, i.e. "Improved flow in \\
healthcare", "Idealized Design of the Clinical Office \\
\end{tabular}} & \multirow[t]{2}{*}{ Organizational behavior change } & 2003 & 848 & 2,15 & 1,502 & \multirow{2}{*}{\begin{tabular}{|l|l|}
5 & $\mathrm{p}<0.01$ \\
\end{tabular}} \\
\hline & & & 2007 & 1129 & 2,80 & 1,565 & \\
\hline \multirow[t]{2}{*}{4} & \multirow[t]{2}{*}{ To implement or develop an electronic medical record } & \multirow[t]{2}{*}{ medical/management control } & 2003 & 838 & 2,60 & 1,580 & \multirow{2}{*}{$p<0.01$} \\
\hline & & & 2007 & 1105 & 3,17 & 1,660 & \\
\hline \multirow[t]{2}{*}{5} & \multirow[t]{2}{*}{ Balanced Scorecard } & \multirow[t]{2}{*}{ medical/management control } & 2003 & 829 & 2,29 & 1,515 & \multirow{2}{*}{$\begin{array}{l}5 \\
6\end{array}$} \\
\hline & & & 2007 & 1111 & 2,81 & 1,596 & \\
\hline \multirow[t]{2}{*}{6} & \multirow[t]{2}{*}{ M } & \multirow[t]{2}{*}{ Patient orientation } & 2003 & 842 & 2,52 & 1,223 & \multirow{2}{*}{$p<0.01$} \\
\hline & & & 2007 & 1105 & 2,96 & 1,242 & \\
\hline \multirow[t]{2}{*}{7} & \multirow[t]{2}{*}{ The national quality registries } & \multirow[t]{2}{*}{ medical/management control } & 2003 & 841 & 2,63 & 1,426 & \multirow{2}{*}{$\begin{array}{ll}6 \\
\end{array}$} \\
\hline & & & 2007 & 1128 & 3,07 & 1,357 & \\
\hline \multirow[t]{2}{*}{8} & \multirow[t]{2}{*}{ Incremental changes through small scale testing } & \multirow[t]{2}{*}{ Organizational behavior change } & 2003 & 818 & 2,56 & 1,361 & \multirow{2}{*}{$\mathrm{p}<0.01$} \\
\hline & & & 2007 & 1079 & 2,97 & 1,317 & \\
\hline 9 & Implementation of Information Systems to support our & medical/management control & 2003 & 847 & 2,77 & 1,474 & $n \leq 001$ \\
\hline & operations (staff administration, telemedicine, digital & & 2007 & 1098 & 3,06 & 1,510 & p<0.01 \\
\hline 10 & Changes to the organizational structure & Organizational structure & 2003 & 853 & 2,80 & 1,444 & $0<001$ \\
\hline & & & 2007 & 1129 & 3,00 & 1,387 & $\mathrm{p}<0.01$ \\
\hline 11 & To develop management review systems & medical/management control & 2003 & 846 & 2,53 & 1,245 & $0 \leq 001$ \\
\hline & & & 2007 & 1102 & 2,72 & 1,259 & $p<0.01$ \\
\hline 12 & To develop methods descriptions, practice guidelines and & Information/communication/training & 2003 & 872 & 3,18 & 1,222 & \\
\hline & instructions etc. & & 2007 & 1139 & 3,37 & 1,196 & $p<0.01$ \\
\hline 13 & Increased information through printed materials, overhead & Information/communication/training & 2003 & 857 & 2,32 & 1,178 & $p<0.01$ \\
\hline & visual materials, lectures, etc. & & 2007 & 1130 & 2,51 & 1,187 & \\
\hline
\end{tabular}


- Working paper, do not distribute -

Table 6. Methods/concepts that have decreased in use between 2003-2007

\begin{tabular}{|c|c|c|c|c|c|c|c|}
\hline $\begin{array}{l}\text { Rank order } \\
\text { (difference in means 2007- } \\
\text { 2003) }\end{array}$ & Measurement & Category & Year & $N$ & Mean & $\begin{array}{l}\text { Standard } \\
\text { deviation }\end{array}$ & Significance \\
\hline \multirow{2}{*}{32} & \multirow{2}{*}{ National/international/regional quality awards } & \multirow{2}{*}{ Problem analysis } & 2003 & 842 & 1,62 & $\begin{array}{r}1,150 \\
\end{array}$ & \multirow{2}{*}{$\mathrm{p}<0.01$} \\
\hline & & & 2007 & 1093 & 1,47 & 0,970 & \\
\hline \multirow[t]{2}{*}{33} & \multirow[t]{2}{*}{ Acquisition of additional financial resources } & \multirow[t]{2}{*}{ Financial issues } & 2003 & 832 & 2,58 & 1,442 & \multirow{2}{*}{$\mathrm{p}<0.01$} \\
\hline & & & 2007 & 1097 & 2,41 & 1,366 & \\
\hline \multirow[t]{2}{*}{34} & \multirow[t]{2}{*}{ Reward systems } & \multirow[t]{2}{*}{ Financial issues } & 2003 & 837 & 1,70 & 1,054 & \multirow{2}{*}{$\mathrm{p}<0.01$} \\
\hline & & & 2007 & 1056 & 1,51 & 0,911 & \\
\hline
\end{tabular}




\section{Discussion}

In this article we describe developmental trends in quality improvement efforts in the Swedish healthcare system by analyzing and comparing the results from two surveys using a longitudinal approach. We report that the overall picture reveals similarities between the two measurements and that there are some important changes in focus. A general aspect is the tendency toward increased external pressure on the leaders in their improvement work. Higher management decisions, patient pressure and decisions made by policymakers have an increasing influence and shape the choices of healthcare managers about where to focus efforts of improvement. This increased pressure from outside the organization is a significant shift from the Internal Collaborative Strategy (ICS) elaborated upon in Olsson et al. (2003). Furthermore, the respondents have not changed their view about improvement work in general. In the following section, we discuss the results and elaborate on possible implications.

\section{Trends and logics of improvement}

Analysis of data shows three major trendlines: Take-control logics; practice-based improvement and patient-centeredness.

\section{Take-control logic}

There are several indications that reveal a pattern of increased usage of medical/management control systems. From a broad perspective this includes formal medical/management control, information-based routines and procedures that managers, clinics and policy makers use to maintain or alter patterns in organizational activities (see e.g. Simons, 1995). These types of concepts and methods include electronic medical record, national quality registers, administrative information systems, balanced scorecard, management review systems, etc. The tendency towards using such methods may be a response to the general question of top management taking responsibility and control over organizational activities in the system as a whole. These types of changes indicates a clearer management focus and increasing use of steering mechanisms in the organizations.

Two lines of development in the take-control logics are clinical pathways and administrative managerial methods. These two might indicate that managers understand the importance of both acknowledging values linked to the pride of being a professional as well as the necessity of developing methods corresponding to needs of higher management and politicians. According to Olsson, Elg and Lindblad (2007) this is a positive trend. Underlining this, the take-control strategy can also be analyzed as a strategy for coping with increased uncertainty in the environment, calling for increasing effort for formalization in healthcare organizations (Saltman, Figueras and Sakellarides, 1998). 
The increased use of management control systems in health care may be viewed as a way to create external pressure and a sense of urgency for change. Evidence suggests that failing to create a sense of urgency has devastating effects on change efforts. In this respect, the increasing external pressures could be viewed as a positive indicator creating optimal conditions for change.

Implications for the healthcare leader's point of view are that information from the environment is often complex and hard to interpret and also transmitted from a variety of different stakeholders. The managerial challenge clearly has to do with ability to interpret information as well as each manager's capacity to attend information. Consequently, greater demands for increasing organizational transparency could in effect lead to focus on reporting systems as well as tension for change at the managerial levels. However, whether substantial change occurs at the same time in the clinical microsystems remains to be confirmed.

\section{Practice-based improvement logic}

This trend is related to the growing use of risk analysis, events where patients have been harmed, and understanding and enhancing work processes through mapping and the use of small-scale tests. Thus, action/event-based problem solving refers to the systematic use of tools, principles and methods which enable analysis and altering of specific activities within the organization that are linked to the actual production of care. Focus on task alignment is important and strengthened by the fact that focus on economy has declined. This is an interesting trend since it balances the traditional focus on improvement from an administrative and economic point of view to a professional, medical point of view. This movement aligns management control systems closer to professional driving forces. This is probably an important feature of management systems able to produce improved outcomes. Consequently, it is a positive trend.

\section{Patient-centeredness logic}

One of the main criticisms discussed in Olsson et al (2003) and elsewhere, is lack of patient focus when improving healthcare. Further, the Olsson et al (2003) study stated that "Health care is a service industry, and its outcomes are produced in collaboration with the patient. The long-term success of health care is, arguably, dependent on our system's ability to appreciate the needs of every single patient as well as of the entire population we care for". Patient-centeredness has improved since 2003. One indicator suggesting this is the leading measurement of drivers for change, which shows an increased change in drivers that come from either the outer organizational context or external environment. Patient needs/complaints are a crucial creator of tension for change. Furthermore, there is evidence that patient-oriented concepts/methods are increasingly used. 


\section{Non-significance of interest}

Except for the significant differences described by the three logics it is worth noting that research as a driver for change and supporting leaders to manage change have the same rating in the two materials. The effect from a number of items rated higher in the previous survey research and managers drop in relative rank and thus are seen as less important drivers for change. This is problematic since research consequently views management as a key to success and sustainability. Possible explanations to this phenomenon may be that managers are heavily loaded by dealing with everyday problems, therefore unwilling to prioritize their own education and supporting networks. Another closely related explanation is that managers do not perceive the knowledge needed to lead change as a separate field of knowledge. Therefore they are unable to understand their own need for knowledge development. When it comes to the low driving force in using evidence or research, this is a worrying sign since healthcare needs to be based on best available knowledge. A possible explanation for this phenomenon is that in practice managers do not get value from research done by coworkers. Thus research is more for self-fulfillment than a contribution to organizational development. This may also be linked to the way research is carried out, where traditional research does not feed anything back to organizations until research is published. This is an overall system problem involving professionals as well as funders of research.

\section{Connecting local and national trends}

The managerial trends described are to some extent characterized by centralization and management control. This is coherent with many reforms suggested by politicians. From this standpoint there seems to be an ongoing movement of centralization and control in Swedish healthcare on both a local and national level. Possible risks are that a strong command and control structure can alienate professionals by narrowing their span of control, which affects their professional pride negatively. At the same time there seems to be a trend where responsibility for change is decentralized, which builds on professional forces. In this survey, Practice-based changes and Practice-based problemsolving indicate such a professional movement. At a national level policy decisions from politicians start to open the Swedish system for different actors to produce different services within the healthcare sector. Centralization of control systems seems to be the basis for decentralization of improvement action in practice.

Since the 2003 survey, national initiatives on evidence-based medicine (EBM) have been far reaching in ambitions. In the 2007 survey we report that there is status quo in the usage of evidence-based medicine. This measurement is of special interest since several of the development initiatives use EBM as a basis. Furthermore, this puts in focus the strategic content for implementing EBM in day to day practice. EBM challenges the

professional autonomy of healthcare professionals since EBM has to do with changing 
behaviour and de-learning. As with implementation of research findings into practice, the implementation strategy should be informed by research. Bero, Grilli et al. and later Grol and Grimshaw suggest interventions to promote behavioural change (Bero and Grili, 1998; Grol and Grimshaw, 2003).

\section{Conclusion}

Higher management decisions, patient pressure and decisions made by policymakers have increasing influence and shape the choices of healthcare managers about where to focus efforts of improvement. Furthermore, we identify three different trends that are prevalent in contemporary Swedish healthcare: Take-control logics; practice-based improvement and patient-centeredness. In a study by Olsson et al. (2007), items specifically attributed to organizations conducting successful improvement were identified. This strategy was in the paper denoted Patient Centered Task Alignment strategy (PTCA). The pattern of PTCA organizations share similar characteristics with the growing developmental trends viewed in this study. For example, one of the major attributes of PTCA is that external pressures have impact on internal action. This is one of the findings indicating that Swedish healthcare organizations may be in the beginning of a transition from an internal collaborative strategy to a patient-centered task-aligned strategy of change. Further research efforts are needed to explore the validity of this argument.

\section{Future research}

Further research is needed in at least two areas. First, we would like to test hypotheses regarding differences in organizational structure, characteristics and improvement work. Second we are interested in studying the data material at the county council level and comparing it with other sources of data, especially the open comparisons data in Sweden.

\section{References}

Anell, A (2005), Swedish health care under pressure. Health Economics 14:237-254.

Banta D. H. and Luce B. R., (1993), Health Care Technology and its assessments. An international perspective, Oxford: Oxford University Press

Beer, M., \& Nohria M., (2000) Breaking the Code of Change, Harvard Business School Press

Bergman, B., \& Klefsjö, B. (2003). Quality - from Customer Needs to Customer Satisfaction. Lund: Studentlitteratur. 
Bero, L., R. Grilli. et al(1998), Closing the gap between research and practice: an overview of systematic reviews of interventions to promote the implementation of research findings. $B M J 317,465-468$

Borgert, L (1992), Organisationer som mode: Kontrasterande bilder av svensk hälso- och sjukvård. Akademisk avhandling, Stockholms universitet: Stockholm

Bourgeois, L.J., MacAllister,D.W., and Mithchell,T.R. (1978), The effects of different organizational environments on decisions about organizational structure. Academy of Management Journal, 21, pp 504- 14.

Cutler, D.M. and McCellan, M (2001), Is technological change in medicine worth it? Health Affairs 20(5): 11-29

Davenport, T.H. and Prusak, L. (1998), Working Knowledge , Boston: Harvard Business School Press

Elg, M. (2001). Performance Measures and Managerial Work -A modified behavior setting approach to the study of usage of performance measures in managerial meetings. Doctoral Dissertation, Linköpings universitet, Linköping.

Ellström, P.-E. (2006). The Meaning and Role of Reflection in Informal Learning at Work. In: D. Boud, P. Cressey, \& P. Docherty (Eds.), Productive Reflection. An Anthology on Reflection and Learning at Work. London: Routledge.

Goldsmith, J. (1994), The impact of new technology on health care costs. Health Affairs 13:3:80- 81

Grol, R. and J., Grimshaw (2003), From best evidence to best practice: effective implementation of change in patient's care. The Lancet 362 (October 11). 1225- 1230 Hall, D.T. and Mansfeild, R. (1971), Organizational and individual response to external stress. Administrative Science Quarterly, 16, 533- 47.

Kazandijan, V. A., \& Lied, T. (1999). Healthcare Performance Measurement: Systems Design and Evaluation. Milwaukee: ASQ

King, D, L., Ben-Tovim, D, I., Bassham, J. (2006), Redesigning emergency department patient flows: Application of lean thinking to health care. Emergency Medicine Australia 18, pp 391-397.

National Healthcare Quality Registries - in Sweden, 2007, Swedish Associations of Local Authorities and Regions) 
Neely, A., Adams, C., \& Kennerley, M. (2002). The performance prism. London: Prentice Hall.

Nolte E and McKee (2003), Measuring the health of nations, BMJ, Vol. 327, No. 7424.

Olsson J, Kammerlind, P, Thor, J., Elg, M (2003). Surveying Improvement Actitivites in Health Care on a National level - The Swedish Internal Collaborative Strategy and its challenges. Quality Management Health Care. Vol 12. No 4. pp 202- 216

Olsson, J., Elg, M., \& Lindblad, S. (2007). System characteristics of healthcare organizations conducting successful improvements. International Journal of Health Organization and Management. 21(3), 283 - 296

Pettigrew, A., Ferlie, E., McKee, L. (1992). Shaping strategic change: making change in large organizations: the case of the National Health Service. London: Sage.

Porras, J. I. and P. Robertson, J. (1993). Organizational development: Theory, practise and research. Handbook of Industrial and Organizational Psychology. M. D. Dunnette and L. M. Hough. Palo Alto, Consulting Psychologists Press. 2.

Pugh D.S, Hickson D.J, Hinings C.R and Turner C. (1968). Dimensions of Organization Structure, Administrative Science Quarterly, 13 :pp. 65-105

Quality and Efficiency in Swedish Health Care - Regional Comparisons 2007, Swedish Association of Local Authorities and Regions and The National Board of Health and Welfare

Saltman, R.B., Figueras, J. and Sakellarides C. (1998), Critically challenges for health care reform in Europe, Buckingham: University Press

Schwartz, W.B. (1994), In the pipeline: A wave of valuable medical technology. Health Affairs 13:3:70-79

Scott, R, W., Gerald, F, D.(2006), Organization and organizing: Rational, Natural and Open Systems Perspectives. Prentice and Hall

Simons, R. (1995). Levers of Control. Boston: HBS Press.

Swedish Code of Statutes, Regeringsformen, 1 chapter, 7§. SFS 1976: 87

Thompson, D, D., Gail, A, W., Steven, J, S. (2003), Driving Improvement in Patient Carelessons from Toyota. JONA. Volyme 33, Number 11, pp. 585-595 
Van de Ven, A., Angle, H. L., and Poole, M. S. (eds.) (2000), Research on the Management of Innovations - the Minnesota Studies (2 ed.), New York: Oxford University Press. 